\title{
The Value Relevance of Accounting Disclosures among Nigerian Financial Institutions after the IFRS Adoption
}

\author{
Yusuf Alkali Mohammed \\ Waziri Umaru Federal Polytechnic Birnin Kebbi, Nigeria, Yusuf Alkali Muhammad Block 11 P flat 005 \\ Maybank Student Residential Building University Utara Malaysia Sintok, Kedah 06010 \\ yusufalkali68@yahoo.com \\ Nor Asma Lode \\ University Utara, Malaysia, Nor Asma Lode Department of Accounting University Utara, \\ Malaysia Sintok, Kedah 06010 \\ asma@uum.edu.my
}

Doi:10.5901/mjss.2015.v6n1p409

\section{Abstract}

This paper discusses about the adoption of International Financial Reporting Standards (IFRS) by the Nigerian financial institutions. Nigeria have been using domestic accounting standard (NGAAP) for banks and non-banks financial institutions known as Statement of Accounting Standards (SAS 10 Part 1 and SAS 15 Part 2) issued in 1990 and 1997 respectively for financial reporting. These domestic standards were adopted from International Accounting Standards (IAS 30) but have not been updated like IAS 30 as reported by the Report on Observance of Standard Codes (ROSC) of Nigeria in 2004 and 2011. The change in accounting regulations is as a result of the weaknesses of NGAAP and low disclosure requirements. IFRS reporting has more disclosures than NGAAP especially for financial institutions. Under NGAAP financial instruments have not been classified as in IFRS. For instance, financial instruments have been classified into four under IAS 39 as; (i) recognised fair value on gain or loss in profit or loss, (ii) are measured at amortised cost for investments held-to-maturity, (iii) measured at amortised cost for loans and receivables, (iv) measured at fair value gain or loss for available-for-sale financial assets recognised in other comprehensive income. Additionally, financial liabilities have been categories into two namely; (i) measured at amortised fair value on financial liabilities through profit or loss and, (ii) measured at amortised other liabilities. Now with the mandatory adoptions of reporting under IFRS by all listed financial institutions, will the accounting disclosures be more value relevant among Nigerian financial institutions?

Keywords: value relevance, financial institutions, disclosures, NGAAP and IFRS

\section{Motivation of the Study}

Demand for relevant accounting disclosures by users is increasing due to the growing complexity of business environments worldwide. Businesses continue to grow with more people participating in the stock market (Kasum, 2007) and comparing financial information between firms of different countries has become significant issue to the investors (Tarca, 2004). The financial sector is the most flourishing sector of the economy that makes a significant contribution to the stock market (Hossain \& Baser, 2011). The financial sector is described as a heavily regulated industry (banks) due to its different business nature of performing money mediators of deficit and surplus components within the economy (Dimitropoulos, Asteriou \& Koumanakos, 2010). Hence, accounting disclosures in this industry could be relevant for capital markets to function effectively.

The existence of functional financial institutions will facilitate development in the stock market (Hossain \& Baser, 2011). Financial institutions need to be integrated into global best practices of financial reporting to attract foreign investments and developed Nigerian stock market (Sanusi, 2010). Report on the Observance of Standard Code (ROSC) in 2011 reports that, financial institutions in Nigeria do not provide full disclosures of accounting information in their published financial statements in accordance with the requirements of Nigerian accounting standards. Furthermore, the accounting practice in the country is also found to have suffered institutional weakness and non-compliance in regulations, rules and standards enforcement in financial institutions. The avoidance of these full disclosures has been attributed to the drastic fall of the Nigerian stock market which also caused crisis in the financial sector as reported by the ROSC in 2011. In view of that, International Financial Reporting Standards (IFRS) were introduced in Nigeria in 2011. Nigerian government made several efforts to improve on the accounting reporting because of its weaknes (Muhammad \& Nor, 2014). The Nigerian government approved and signed into law, the Financial Reporting Council (FRC) Act, 2011 to replace the Nigerian Accounting Standards Board (NASB) Act 2004. Several studies provide evidence that emerging 
markets have improved on the value relevance of accounting disclosures after adoption of IFRS (Kargin, 2013; Konstantious \& Athanasios, 2011; Alali \& Foote, 2012).

Many studies were conducted on the relationship between accounting disclosures (book value, earnings, net income, other comprehensive income and cash flows) with stock prices or returns in developed markets (e.g., Amir, Harris \& Venuti 1993; Dechow 1994; Aboody \& Lev, 1998; Francis \& Schipper, 1999; Barth \& Beaver, William \& Landsman, 2000), and emerging markets (Chen, Charles, Chen and Su, 2001; Alali and Foote, 2012; Tharmila and Nimalathasan, 2013). Similarly, a few value relevance studies have been conducted in Nigeria (e.g., Abubakar, 2012; Titilayo, 2011; Abiodun, 2012). These studies document evidence on the value relevance of accounting disclosures in Nigeria, although they indicate conflicting results. However, the studies were conducted before the adoption of IFRS in Nigeria.

In our previous paper (Muhammed \& Nor, 2014) we discussed efforts and challenges of IFRS adoption in Nigeria in 2012. Therefore, the objective of this study is to determine the disclosures under NGAAP and IFRS after the adoption of new accounting reporting. The study will be significant to investors, policy makers, professionals and regulatory bodies on the additional disclosures in the new accounting regime. Previous literature have shown that IFRS provide more transparent, more disclosures than domestic accounting. Despite the significance of financial sector in the Nigerian economy little or none has been studied. However, this study will examine the major improvement on disclosures from the new accounting regulations (IFRS) in comparison to NGAAP reporting among Nigerian financial institutions.

This paper is further divided into sections as follows. Section 2 the Nigerian stock market and banks divided into 2 subsections as 2.1 The Nigerian stock market and 2.2 the Nigerian banks. This is followed by section 3 the value relevance concepts. Next is section 4 prior studies on value relevance. Section 5 is the NGAAP vs IFRS for financial institutions. Lastly, section 6.0 is the conclusion of the study.

\section{Nigerian Stock Market and Banks}

\subsection{The Nigerian Stock Market}

One of the challenges in adopting IFRS in Nigeria is the stock market. Quality reporting in less developed countries is very difficult to achieve as compared to developed countries like US and UK and even some developing countries like South Africa and Mexico (Prather-Kinsey, 2006). The immaturity of the market scared away investors into the country, as reporting system provides not much protection to investors. IFRS becomes imperative given that businesses are becoming more complex in the country with multinationals firms and banks. As a result of adoption to IFRS in developing countries foreign investment into capital market will improve (Gordons, Loeb \& Barros, 2012).

In 2010, Foreign Direct Investment in the country becomes weaker from $\$ 6.9$ billion in the year 2007 to $\$ 3.94$ billion in 2009 as a result of risk perceptions by the investors. These figures might have been inflated by the international community as government was committed to providing a scientific risk managing approaches (NASB, 2010). The fall out of stock market (2008) in Nigeria and global financial crisis especially in banks compound the issue of quality reporting in the country. These financial crisis and failure of banks was a serious challenge confronting NSE, especially as it relate to financial reporting.

Other challenges experience by the stock market are; (i) non-provision of security market regulators involvement in the appointments and resignation or termination of auditors; (ii) no provision in the CAMA, 1968, other laws and regulations on rotation or joint work of auditors, even though the NSE monitors with the compliance of financial reporting requirements of firms whose debt securities or equity are traded publically (NSE, 2010). Enforcement of regulation by SEC is found to be weak (ROSC, 2010); (iii) Lack of capacity by the NSE to monitor effectively with accounting standards has been a challenge. For example few cases of suspension were issued to firms in the NSE for financial reporting breach of regulation (NSE, 2009); (iv) delisting of firms' by NSE is the only sanction allow by CAMA 1968, even though audited financial statements of firms listed can only be published with the approval of stock exchange,(v) un-ethical and professional behaviors of the preparers of financial information by non-disclosure of accounting information; and (vi) over statement of balance sheet items by the preparers of financial statement, resulted into over bolted stock market which caused failure of the stock market in 2008.

Firms 'experienced difficulty from the preparation of accounts and filling obligations using IFRS requirements for the fiscal year 2012 audited accounts. This has made the NSE to extend time of submission to 30 days after the required period of submission. This will ensure firms and advisors the challenges of adopting IFRS, as well as improved regulatory approval levels, which include the FRC of Nigeria. The weakness of the regulation and challenges in the financial market has led to the loss of Millions of dollars in the financial market which adversely affect the economy. Financial institutions 
are bound by the rules and regulations that are different from non-financial institutions. Therefore, choice of financial institutions is important in research, because larger financial institutions are expected to have more transparent financial reporting practices (Mohan \& John, 2011).

In the second half of 2008, the global economic crisis came into light and leads to collapse to financial institutions and non-financial institutions worldwide. The collapse of these institutions raised many questions on value relevance of accounting information (Umoren, 2009). Thus, firms fail to disclose financial information to the users. The availability of relevant financial reports is useful to users for decisions making (lyoha, 2012). The need for the disclosure of financial reporting is important to the users due to the growing number of companies in the international market. For example IFRS 7 Financial Instrument: Disclosure, for banks and non-banks financial institutions has different disclosure requirements with Nigerian accounting standards. Hence need for new process, systems, and internal control to be in place for having relevant accounting information (KPMG, 2011).

Results from the NSE have shown the number of financial institutions registered with the stock markets has declined due to the delisting voluntary, regulatory instruction, reforms or expansions within the operational sectors. For the past ten years to June 2013, not fewer than 63 firms delisted from the NSE (Nwachukwu, 2013). As at 2009 there are 24 banks supervised by the CBN with 3 banks not listed in the NSE. While in the year 2011 the numbers of banks were also reduced to 19 and period 2012 to 2013 were further reduced to 14 banks as a result of delisting by the NSE for not meeting regulatory requirements as in table 1.1

Table 1.1 Listed Financial Institutions

\begin{tabular}{ccccccccc}
\hline S/No & Year & Banks & Insurance & Leasing & Mortgage institution & Funds Administrator & Micro finance & total \\
\hline 1 & 2009 & 21 & 30 & 1 & 4 & 6 & 0 & 62 \\
2 & 2010 & 21 & 30 & 1 & 4 & 6 & 0 & 62 \\
3 & 2011 & 19 & 30 & 0 & 4 & 7 & 0 & 60 \\
4 & 2012 & 15 & 29 & 0 & 4 & 10 & 2 & 57 \\
5 & 2013 & 15 & 28 & 0 & 5 & 10 & 2 & 60 \\
\hline
\end{tabular}

Source: NSE, 2014

\subsection{The Nigerian Banks}

The report of World Bank in both 2004 and 2011 recommended that the improvement of quality accounting reporting not only in banks but in other sectors in the country to attract foreign investors. Therefore, developing country such as Nigeria requires harmonization of accounting practice with the global practice of quality reporting in the financial market given that accounting information improve as a result of adoption to IFRS (Liu, Yao, Orleans \& Yao, 2012). Quality accounting information is sufficient in making a significant change in the users' decision making. Therefore, weak capacity building, non-disclosure of relevant accounting policy and weak enforcement on the use of accounting standards by the regulatory agencies lead to publishing low quality financial information. In Nigeria the banking sector loss huge amount of money (between USD9, 333, 962, 642 to USD 12,578,616, 352) in the financial market in 2008, which leads to the merger and acquisition of many banks in the country (World Bank, 2011).

Pressures from legislations, developing and improving of accounting reporting standards to meet up with international capital market demands become a challenge to Nigerian banks. Studies by the World Bank group in 2004 and 2011 in Nigeria, reported that financial reporting in the country was weak with no updates to meet the global business reporting. Another challenge identified by the report of World Bans is the non-disclosure of accounting information and presentation of improper published accounts by banks in the country as the causes of banks failure in 2008. Banks concealed their loss to the Central Bank of Nigeria (CBN) when a special inspection was carried out by CBN (Sanusi, 2011). Drastic rise of non-performing loans from $5 \%$ in 2008 to $60 \%$ by the end of 2009 was a challenge in the banking sectors (World Bank, 2011).

This practice rapidly caused the sudden fall of stock prices as customers defaulted on the margin loans and having a very large non-performing loans portfolio by the banks, which led to the fall of stock prices, default on the margin loans by the customers, that form the larger parts of no-performing loan portfolio for the banks. The Central Bank of Nigeria, immediately noticed this challenged, it move for the adoption of IFRS for banks. This will achieve market confidence, to be characterized by a highly transparent and quality financial reporting that is based on the acceptable financial reporting standards. The CBN first move was to improve bank supervision through improving on the risk-based supervision and consolidated supervision. Training of banks and professionals on the use of new accounting system has been costly in terms of time and implementations especially in reporting of financial statements (Sanusi, 2010). 


\section{Value Relevance Concepts}

Value relevance studies have been categorised into three classifications by Holthausen and Watts (2001). The first classification is the relative association studies that describe the increase or decrease on the association between stock prices with substitutive bottom-line measures. For instance, Amir et al. (1993) compared value relevance of accounting information between US and Non-US GAAP adopting relative association. Secondly, incremental association studies, which examine whether long period accounting numbers of interest can be helpful in explaining market returns or values when other specified variables are given. For example, Holthausen et al. (2001) cited in Ventachelun (1996), investigated incremental relationship in a value risk management derivative using regressions in equity market values from different on and off-balance sheet items. Lastly, the marginal information studies, where accounting numbers are examined as to whether they improve on the information set accessible to investors using event studies to decide if accounting numbers have any relationship with value changes.

Value relevance is the "association between accounting amounts and security values" (Barth \& Beaver, 2000). The ability for financial reporting information to summarise and capture information that affects share values has been empirically tested as a statistical association between accounting and market values" and mapping from financial statements to "intrinsic" value (Aboody, Hughes \& Liu, 2002; Hellström, 2006; Tharmila \& Nimalathasan, 2013). Similarly, value relevance of financial information can be predictive and statistically measured through the relationship between stock market values or returns from the information reported by the financial statement (Barth et al., 2001), with the ability of the disclosed information in financial statement to capture and summarises firm value (Beisland, 2009; Kargin, 2013).

However, Beisland (2009) reports that value relevance researches are associated with market efficiency as they can provide the relationship between accounting numbers and stock prices. In many studies, Ohlson model (1995) has been employed to explore associations between the market value of equities and main financial information disclosed variables, such as book value per share (as balance sheet) and earnings per share (as income statement), other comprehensive income and cash flows.

The International Accounting Standards Committee (IASC) 1989 reported the role of accounting information to be both confirmatory and predictive to market values and accounting numbers as well as interrelated to each other. Thus, the IASB in 2010 stated that, "Financial information needs to be predictive or forecasted to have predictive value; financial report with predictive value is used by users in making their predictions". Ebaid (2012) studied influence of accountingbased methods on market returns and prices and their predictive values to be considered as the value relevance of accounting disclosures. Thus, generally book value is value relevant when it can determine stock prices (Kargin, 2013). Similarly, Vishnani \& Shah (2008) report that, "Value relevance" denotes power of the financial information stated in the financial reports to explain the stock market price measures.

\section{Prior Studies on Value Relevance}

Early value relevance literature on financial instruments investigated whether fair value disclosed can provide incremental value information to either recognised fair value or historical cost. Majority of these studies provide supporting proof, for e.g., Barth et al. (1995) and Eccher, Ramesh and Ramu (1996). The basic idea is to expand this study in the reclassification of assets and liabilities by adopting the total assets and liabilities recognised under NGAAP and IFRS for both non-financial and financial assets and liabilities. Therefore, the difference between disclosures on assets and liabilities under different regimes should be value relevance which can explain changes of share prices and returns.

Furthermore, Barth (1994) measures value relevance of banks' investment securities using fair value and historical cost for both assets and related earnings. The study provides evidence on the two methods on relative and incremental explanatory power with relative measurements error. He documents that fair value measurement estimates from investment securities have significant explanatory power over historical costs. Fair value on gains and losses from securities investments has no significant incremental power; historical cost provides significant incremental explanatory power over fair value. However, Ahmed and Takeda (1995) document different results compared to Barth (1994) with the controlling effects of other net assets. They found that both realised and unrealised gains and losses have significant positive effect in normal periods on bank returns, although realised security gains and losses have lower significant effect in a period of low earnings and capital.

Goodwill, as an intangible asset, is reported to be value relevant among the banks in the European zone, with the introduction of IFRS and fair value measurements (Isidro \& Grilo, 2012). In addition, Wang, Alam and Makar (2005) examine whether derivatives disclosures under SFAS 119 and SFAS 113 on newly introduced fair value data using complete time series can provide additional information content that goes beyond earnings and book value. Their findings indicate that notional amount on banks' disclosures are value relevant. The possible generalisation of this result is that 
equity values are linked to different types of unrecognised losses, and gains in most cases, are not likely to produce the needed hypothesis on the positive association between unrecognised gains and losses, and equity values in the two studies.

In other studies of Barth, Landsman and Wahlen (1995) it is prove that fair value in earnings is more value relevant than historical cost earnings with no reflection of share prices in the incremental volatility in banks. They provide evidence of violation of regulatory requirements of banks under fair value compared to historical cost. In other words, fair value in banks assists in predicting capital violation regulations. Equally, Khurana and Kim (2003) in their study on value relevance of fair value disclosure, validate the hypothesis that there is more informativeness in fair value than historical cost in accounting reporting for financial instruments. The study used SFAS No. 17 and 115 on fair value disclosures by bank holding firms over the period of 1995-1998. Furthermore, they state that historical cost estimates on deposit and loans have more value relevance that fair values. However, loans and deposits are more actively traded and are usually involved subjectively in respect to the assumption and methods used in fair value estimations.

In the work of Prather-kinsey (2006) two different capital markets using earnings announcement (Johannesburg Stock Exchange (JSE), South Africa \& Bolsa Mexicana de Valores (BMV) Stock, Mexico), reports that, testing the association between book value and earnings with firm market value. He reports that book values were value relevant in both markets, with significant positive association between earnings or equity values and market value in the reported financial statements in the two markets. There was also significant immediate increase in earnings announcements in the JSE.

From the financial statements, net income is equal to total revenue plus gains minus expenditures and losses. The comprehensive income equals net income in addition to other items collectively referred to as other comprehensive income. Studies have tried to identify the value relevance of components of other comprehensive income and market prices. For example, Cimini and Mechelli (2013) posit that gains and losses on re-measuring available-for-sale financial assets (AFS) on financial institutions to be value relevant in banks. They also found other sectors to be less transitory. Similarly, Cahan, Courtenay, Gronewoller, and Upton (2000) found that assets revaluation increment and foreign currency adjustments under $\mathrm{OCI}$ have no incremental power over net income.

While, Jones and Smith (2011) extend the literature of value relevance on gains and losses as reported under Other Comprehensive Income (OCI), and as Special Items (SI), to predict cash flows. The results of the findings provide evidence that both $\mathrm{OCI}$ and SI gains and losses as value relevant. In contrast, SI gains and losses exhibit no persistence, while $\mathrm{OCl}$ exhibits negative persistence. There is stronger predictive value under SI gains and losses for forecasting of future cash flows and net income with $\mathrm{OCl}$ having weaker predictive value on gains and losses. Cimini and Mechele (2012) observe 125 European listed firms in the period 2009-2010 to determine value relevance of OCl. The findings of their study report significant positive value relevance of $\mathrm{OCl}$ related to net income and gains or losses available for sale financial assets.

Moreover, Dhaliwal, Subramanyam and Trezevant (1999) examine the association between stock prices and comprehensive income in order to determine whether comprehensive income measures has better performance measures than net income. Conclusive evidence is reported showing net income with more superior measures in determining stock returns. Components of other comprehensive income were also examined and found that unrealized gains and loss have incremental content for stock returns in financial services. In contrast, Kanagaretnam, Mathieu, and Shehata (2009) provide evidence that reported net income is a better predictor than other comprehensive income components.

In the study of Mechelli and Cimini (2014), they state that, net income is more value-relevant than comprehensive income $(\mathrm{Cl})$, but total $\mathrm{OCl}$ for the period adds relevant information on net income for those items already disclosed in net income and book value. Additionally, Dhaliwal et al. (1999) found improvement on the association between returns and income as well as $\mathrm{OCl}$. Furthermore, Lee and Park (2013), by adding control variables (audit size) report incremental value relevance of $\mathrm{OCl}$, the result showing that there is incremental value relevance to the aggregate $\mathrm{OCl}$.

Studies conducted on value relevance of cash flows have produced inconclusive and mixed results (Charitou, 1997). Based on this assertion, the hypotheses of this study are to provide support with regards to prior results that have been made by the researchers, as well as to re-examine prior studies that investigated the value relevance of cash flows. Most hypotheses conducted by other researchers have been inconclusive with mixed results.

Dimitropoulos, Asteriou and Koumanakos (2010) investigate value relevance of earnings and cash flows within the banking industry, considering other risk factors in the industry. They report that earnings have incremental information content that are beyond cash flow. In addition, there is positive impact but not significant association with returns earnings and other risk factors having negative impact from the valuation process with regards to bank size. Charitou (1997) proved that cash flows have more information content than earnings when explaining security returns. 
However, the association between future operating cash flows and earnings increases over time (Kim \& Kross, 2005). In contrast, Habib (2008), in his study reports mixed results as: (i) there is greater explanatory power in earnings than cash flows with less statistical significance; and (ii) there is also stock returns incremental information content for earnings and cash flows. Cash flows incremental information content from operations seem to improve with the earnings decrease in performance (Liu \& Schaefer, 1996).

In the same way Barth and Cram et al. (2001) show that components of each accrual reflect several information contents, using components of accruals to predict future cash flows from the studies of content related to future cash flows. Each of the components has shown significant relationship in predicting the future cash flows. In another study of Kim and Kross (2005) the relationship between future operating cash flows and current earnings shows increases over time. Furthermore, they used investment opportunity to determine relative increment of cash flows from operating activities and accruals in firm valuation process and found it to be value relevant. Kumar and Krishnan (2008) report that cash flows from operating activity provide increased value relevance at low investment opportunity.

Prior literature provides mixed results on the value relevance of accounting information as measured in balance sheet, income and expenditure, comprehensive income and cash flows statements. Balance sheet disclosures on assets and liabilities provide information needed by the investors for decision-making in financial institutions. Thus, Nigeria being the second biggest capital market in Africa after South Africa, expects accounting disclosures to be more value relevant to investors under the new accounting reporting.

\section{NGAAP vs IFRS for Financial Institutions}

Basically, there are more disclosures under IFRS than NGAAP among Nigerian financial institutions. Under IFRS most of the assets are measured at fair value with only few measurement on amortised cost or historical cost while, under NGAAP all assets are measured at historical cost. For instance, financial instruments for IFRS have been classified into four under IAS 39 as; (i) recognised at fair value on gain or loss in profit or loss account, (ii) are measured at amortised cost for investments held-to-maturity, (iii) measured at amortised cost for loans and receivables, and (iv) measured at fair value gain or loss for available-for-sale financial assets recognised in other comprehensive income. Additionally, financial liabilities have been categories into two namely; (i) measured at amortised fair value on financial liabilities through profit or loss and, (ii) measured at amortised other liabilities.

Specifically, there are two types of accounting standards for financial institutions as banks and non-banks financial institutions in Nigeria, namely: (i) Statement of Accounting Standard 10 Part 1 (referred to as "SAS 10 Part 1") issued in 1990; and (ii) Statement of Accounting Standard 15 Part 2 (referred to as "SAS 15 Part 2") issued in 1997. Because of the requirement to provide new development in non-banks financial institutions, SAS 15 Part 2 was issued even though banks to some extent perform similar activities to other financial institutions. Meanwhile, SAS 10 Part 1 and SAS 15 Part 2 are adopted from IAS 30: disclosures in the Financial Statements of Banks and Similar Financial Institutions of 1987. SAS 10 Part 1 covers all aspects of the banking sector for financial reporting (SAS 10 Part 1). SAS 15 Part 2 provides guidelines for accounting policies and accounting methods required by the Non-Bank financial institutions. Therefore, both banks and non-bank financial institutions are mandated to prepare financial report using SAS 10 Part 1 and SAS 15 Part 2 from 1990 and 1997, respectively. Although the standards have been replaced by IFRS 7, IAS 39 even though, IFRS 7 and IAS 39 are to be applied to all firms engaged in financial instruments, it can be assumed that the effect of the standards will be on financial institutions, because financial instruments account for more than $90 \%$ of assets and liabilities on average (Bischof, 2009)

The IFRS 7 Financial Instrument: Disclosures issued by IASB in August 2005, with the effective commencement date from $1^{\text {st }}$ January 2007 to improve on the disclosure requirements of capital and financial instruments. IFRS 7 complements the amended IAS 1 Presentation of Financial Statements-Capital Disclosures for disclosure on an entity's capital. The disclosure requirement under IFRS 7 is for the usefulness of financial instruments to firms, level of risk and its nature associated with those financial instruments, in both quantitative and qualitative terms (IASB, 2005).

The first exposure draft of the standards was issued in 2004 as Exposure draft ED 7 Financial Instruments: Disclosures. On $18^{\text {th }}$ August 2005, the standard became effective but earlier application of the standards before 2007 is encouraged. The introduction of the IFRS7 is to have new requirements that will improve on information disclosure for financial instruments in an entity's financial reporting (IASB, 2004). The standard is applicable to all firms engaged in financial instruments; financial institutions could likely be most affected because on the average, total assets and liabilities consist of more than $90 \%$ of disclosures (Bischof, 2009). IFRS 7 is to be applied by all firms that use all types of financial instruments (IFRS 7.3a).

The Standard replaced IAS 30 Disclosure in the Financial Statement of Banks and Similar Financial Institutions 
and amendment of IAS 32 Financial Instruments: Disclosure and Presentation. In 2008, IAS 32 was amended to include obligations and instruments arising from liquidations by adding it to paragraph 3(f) of IFRS 7 for exemptions and scope for those instrument categories as equity. Additionally, greater amendments and improvements of IFRS 7.3; (a) were made from IAS 27, IAS 28 and IAS 31 on disclosures in the individual entity's financial statements for accounting on joint ventures, associates, and subsidiaries in line with IAS 39 (deleted) (although replaced with IFRS 9). There has been constant update of the standards from 2010 to 2011 with the new amendments that has taken up from effect on $1^{\text {st }}$ January 2013 (Example: Disclosure: Offsetting Financial Assets and Financial Liabilities issued 16 th December 2011). The most important changes made are in the area of, (i) exposure-related risk from the quantitative data reported by the management of the entity; (ii) provision of grounds for sensitivity analysis of market risk exposed by the entity at the reporting period by exposing equity, profit or loss-risk effect from the changes that are reasonably conceivable in the period; (iii) disclosure of quality credit from financial assets that are either impaired or past due; (iv) presentations of different disclosures of assets that are financial but are either impaired or past; and (v) carrying amounts disclosure of financial liabilities and financial assets from the classifications as in IAS 39, with net gains and losses in each of the categories; and

New disclosures have been added to IFRS 7 with regards to financial instruments that are required by IAS 32 and superseded by the disclosure requirement of IAS 30 for Financial Statements of Banks and Similar Financial Institutions. The remaining part, Financial Instruments in IAS 32 has been transferred to IFRS 7 leaving financial instruments presentation matters in IAS 32. In the IFRS disclosure, certain categories of instruments in relation to IAS 39 for measurement recognition are required to be under classifications of instrument under IFRS 7(IFRS 7, IN5b). The standards require two essential categories for the disclosure requirements. Firstly, information about the significance of financial instruments, that requires significant disclosures of business performance and financial position from balance sheet, income statements and equity and other disclosures. Secondly, the standard states the nature and the level of business disclosure as exposed to risk arising from financial instruments. The disclosure requirements are characterised as qualitative, quantitative, credit risk, liquidity risk and market risk (IFRS 7; IN5b). The standards are set in order to provide a more transparent financial report to users on the company's exposures associated to risk as well as to how to handle those risks arising from those exposures (Muthupandian, 2012).

Table 2: Summary of NGAAP vs IFRS for Financial Instruments

\begin{tabular}{|c|c|c|}
\hline Disclosures & NGAAP & IFRS \\
\hline $\begin{array}{l}\text { Fair value of financial } \\
\text { Investment Security }\end{array}$ & $\begin{array}{l}\text { Classified as short term or long term } \\
\text { investments }\end{array}$ & $\begin{array}{l}\text { IAS39 fair value through profit and loss (held for trading) fair value at other } \\
\text { comprehensive income (available for sale) at maturity and loans and receivables }\end{array}$ \\
\hline Intangible assets & Part of property, plant and equipment & They are separated individually \\
\hline Financial assets & Reported separately & IAS 39 classification as financial asset \\
\hline Assets & $\begin{array}{l}\text { Short term investments measured at market } \\
\text { value, lower cost and at revalued amount or } \\
\text { long term cost, }\end{array}$ & $\begin{array}{l}\text { All financial assets are to be measured at fair value except, loans and } \\
\text { receivables unquoted equity instruments and held at maturity assets. }\end{array}$ \\
\hline Liabilities & $\begin{array}{l}\text { Deferred tax income measured or calculated } \\
\text { under NGAAP carrying amounts of assets } \\
\text { and liabilities }\end{array}$ & $\begin{array}{l}\text { Measured at amortised cost. This consist of deposit form banks, customers } \\
\text { deposit and borrowings account interest payable from IFRS carrying amounts of } \\
\text { assets and liabilities }\end{array}$ \\
\hline Net fees and commission & Credit fees classified to interest income & Accrued interest income classified using effective interest rate $(E I R)^{1 *}$ \\
\hline Short term investment & $\begin{array}{l}\text { Recognised as part of trading income or } \\
\text { losses in the income statement }\end{array}$ & $\begin{array}{l}\text { Classified as held for trading, available-for-sale- fair value gains or losses on } \\
\text { held for trading investments are recognised under net gains and losses on } \\
\text { financial instruments }\end{array}$ \\
\hline $\begin{array}{l}\text { Foreign currency } \\
\text { translation }\end{array}$ & $\begin{array}{l}\text { Differences are shown on the face of income } \\
\text { statements }\end{array}$ & Differences are shown a component of other comprehensive income \\
\hline $\mathrm{OCl}$ & Not available & In addition to $\mathrm{Cl}$ \\
\hline Interest expenses & $\begin{array}{l}\text { Lending fees borrowing from foreign financial } \\
\text { institutions paid in advance or amortised }\end{array}$ & Classified as interest expenses \\
\hline $\begin{array}{l}\text { Net gains or losses- } \\
\text { financial assets held for } \\
\text { trading }\end{array}$ & Not categories as financial instruments & Held for trading (either for selling or repurchasing \\
\hline Income tax expenses & $\begin{array}{l}\text { Granted at concessionary rate no recognition } \\
\text { for staff benefits or amortised }\end{array}$ & Amortised to staff expenses over loan life \\
\hline Deposits & $\begin{array}{l}\text { Stated as exclusive of all accrued interest } \\
\text { payable }\end{array}$ & $\begin{array}{l}\text { Financial liabilities amortised cost included in interest accrued as EIR from IAS } \\
39\end{array}$ \\
\hline $\begin{array}{l}\text { Fair value available for } \\
\text { sale financial asset }\end{array}$ & $\begin{array}{l}\text { Differences are shown on the face of income } \\
\text { statements }\end{array}$ & $\begin{array}{l}\text { Recognised in other comprehensive income and transferred to fair value reserve } \\
\text { in statement of financial position }\end{array}$ \\
\hline
\end{tabular}

Source: SAS and IFRS, 2014 by the author

${ }_{1}^{1}$ Diamond bank defined EIR as the rate which exactly discount the cash flows to zero 


\section{Conclusions}

Studies on value relevance of accounting information on the new regime have not been new specifically in developed countries. However, study in this area is still new in Nigeria, taken cognizance that new accounting regulations for listed firms commenced 1st January, 2012. This study looked at the NGGAP and IFRS adoption on the value relevance of accounting information and also the differences between the two regimes. The study examined financial institutions because they are mostly affected by changes and having more disclosures under IFRS.

This article pursues to improve the literature as it examined the disclosure requirements under NGAAP and IFRS. To achieve this we explore the differences between the disclosures as reported under IFRS and NGAAP under IFRS and SAS as reported on the published account and notes to the accounts. This is assumed to offer interesting evidence on whether there are more disclosures under IFRS than NGAAP to provide more relevant accounting information. It has been established that IFRS has additional disclosures especially for financial instruments. For instance, IAS 32, 39 have been used to classify financial instruments which has not been found under NGAAP.

This study do not provide enough evidence that IFRS is more value relevant than NGAAP. Therefore, further study can be conducted on the relationship between accounting numbers with stock prices or returns, for the pre-adoption 2009 to 20111 and 2012 to 2014 after the adoption of IFRS for listed firms. This will provide evidence whether accounting numbers are more value relevant under IFRS than NGAAP.

\section{References}

Abiodun, B. Y. (2012). Significance of accounting information on corporate values of Firms in Nigeria. Research Journal in Organizational Psychology \& Educational Studies 1(2), 1(2), 105-113.

Aboody, D., Hughes, J., \& Liu, J. (2002). Measuring value relevance in a (possibly) inefficient market. Journal of Accounting Research, 40(4), 965-986.

Aboody, D., \& Lev, B. (1998). The Value Relevance of Intangibles: The Case of Software Capitalization. Journal of Accounting Research, 36, 161-191.

Ahmed, A. S., \& Takeda, C. (1995). Stock market valuation of gains and losses on commercial banks' investment securities An empirical analysis Anwer. Journal of Accounting and Economics, 20, 207-225.

Alali, F. a., \& Foote, P. S. (2012). The Value Relevance of International Financial Reporting Standards: Empirical Evidence in an Emerging Market. The International Journal of Accounting, 47(1), 85-108. doi:10.1016/j.intacc.2011.12.005

Amir, E., Harris, T. S., \& Venuti, E. K. (1993). A Comparison of the Value- Relevance of U . S . versus Non-U . S . GAAP Accounting Measures Using Form 20-F Reconciliations. Journal of Accounting Research, 31, 230-264.

Baboukardos, D., \& Rimmel, G. (2014). Goodwill under IFRS: Relevance and disclosures in an unfavorable environment. Accounting Forum, 38(1), 1-17a b s t r a c t The accounting treatment of pu. doi:10.1016/j.accfor.2013.11.001

Barth, M. E. (1994). Fair Value Accouting: Evidence from Investment Securities and the Market Valuation of Banks. The Accounting Review, 69(1), 1-25.

Barth, M. E., \& Beaver, W. H. (2000). The Relevance of Value Relevance Research. In Journal of Accounting \& Economics conference (pp. 1-41).

Barth, M. E., Beaver, W. H., \& Landsman, W. R. (1998). Relative valuation roles of equity book value and net income as a function of financial health. Journal of Accounting and Economics, 25, 1-34.

Barth, M. E., Cram, D. P., \& Nelson, K. K. (2001). Accruals and the Prediction Flows of Future Cash. American Accounting Association, 76(1), 27-58.

Barth, M. E., Landsman, W. R., \& Wahlen, J. M. (1995). Fair value accounting: Effects on banks' earnings volatility, regulatory capital, and value of contractual cash flows. Journal of Banking \& Finance, 19(3-4), 577-605. doi:10.1016/0378-4266(94)00141-0

Beisland, L. A. (2009). A Review of the Value Relevance Literature. The Open Business Journal, 2(1), 7-27. doi:10.2174/1874915100902010007

Bischof, J. (2009). The Effects of IFRS 7 Adoption on Bank Disclosure in Europe. Accounting in Europe, 6(2), $167-194$. doi:10.1080/17449480903171988

Black, E. L., \& White, J. J. (2003). An international comparison of income statement and balance sheet information : Germany , Japan and the US. European Accounting Review, 12(1), 29-46. doi:10.1080/0963

Brown, P., \& Ball, R. (1968). An Empirical Evaluation of Accounting Income Numbers. Journal of Accounting Res, 6(2), $159-178$.

Cahan, S. F., Courtenay, S. M., Gronewoller, P. L., \& Upton, D. R. (2000). Value Relevance of Mandated Comprehensive Income Disclosures. Journal of Business Finance \& Accounting, 27(9), 1273-1301.

Charitou, A. (1997). The role of cash flows and accruals in explaining security returns: evidence for the UK. European Accounting Review, 6(4), 629-652. doi:10.1080/09638189700000005

Chen, S., \& Wang, Y. (2004). Evidence from China on the value relevance of operating income vs. below-the-line items. The International Journal of Accounting, 39(4), 339-364. doi:10.1016/j.intacc.2004.06.012

Chen, Charles, J., Chen, S., \& Su, X. (2001). Is accounting information value-relevant in the emerging Chinese stock market? Journal of International Accounting, Auditing and Taxation, 10(1), 1-22. doi:10.1016/S1061-9518(01)00033-7 
Choi, W. (2007). Bank Relationships and the Value Relevance of the Income Statement: Evidence from Income-Statement Conservatism. Journal of Business Finance \& Accounting, 34(7-8), 1051-1072. doi:10.1111/j.1468-5957.2007.02023.x

Cornett, M. M., Rezaee, Z., \& Hassan, T. (1996). An investigation of capital market reactions to pronouncements on fair value accounting. Journal of Accounting and Economics, 22, 121-154.

Dechow, P. M. (1994). Accounting \& Economics The role of accounting accruals. Journal of Accounting and Economics, 18, 3-42.

Dhaliwal, D., Subramanyam, K. R., \& Trezevant, R. (1999). Is comprehensive income superior to net income as a measure of firm performance? Journal of Accounting and Economics, 26(1-3), 43-67. doi:10.1016/S0165-4101(98)00033-0

Dimitropoulos, P. E., Asteriou, D., \& Koumanakos, E. (2010). The relevance of earnings and cash flows in a heavily regulated industry: Evidence from the Greek banking sector. Advances in Accounting, 26(2), 290-303. doi:10.1016/j.adiac.2010.08.005

Dontoh, A., Radhakrishnan, S., \& Joshua, R. (2007). Is stock price a good measure for assessing value-relevance of earnings? An empirical test. Review of Managerial Sciences, 1, 3-45.

Dung, N. V. (2010). Value-Relevance of Financial Statement Information : A Flexible Application of Modern Theories to the Vietnamese Stock Market I. Theoretical Foundations - Ohlson Model ( 1995 ) and Proposition of. Quartely Journal of Economics, 84, 488500 .

Easton, P. D. (1998). Discussion of Revalued Financial, Tangible, and Intangible Assets : Association with Share Prices and NonMarket-Based Value Estimates. Journal of Accounting Research, 36, 235-248.

Ebaid, I. E. (2012). The value relevance of accounting-based performance measures in emerging economies The case of Egypt, 35(1), 69-88. doi:10.1108/01409171211190814

Eccher, E. A., K. Ramesh, \& Ramu, S. T. (1996). Fair value disclosures by bank holding companies. Journal of Accounting and Economics, 22, 79-117.

Eng, L. L., Sun, L., \& Vichitsarawong, T. (2013). The valuation properties of earnings and book values reported under IAS, domestic GAAP and U.S. GAAP: Evidence from China, Hong Kong, Japan, Korea and Singapore. Advances in Accounting, 29(2), 278285. doi:10.1016/j.adiac.2013.09.005

Francis, J., LaFond, R., Olsson, P., \& Schipper, K. (2005). The market pricing of accruals quality. Journal of Accounting and Economics, 39(2), 295-327. doi:10.1016/j.jacceco.2004.06.003

Francis, J., \& Schipper, K. (1999). Have Financial Statements Lost Their Relevance ? Journal of Accounting Research, $37(2), 1999$.

Goodwin, J., \& Ahmed, K. (2006). Longitudinal value relevance of earnings and intangible assets: Evidence from Australian firms. Journal of International Accounting, Auditing and Taxation, 15(1), 72-91. doi:10.1016/j.intaccaudtax.2006.01.005

Gordon, L. A., Loeb, M. P., Zhu, W. (2012). No Title The impact of IFRS adoption on foreign direct investment. Journal of Accounting and Public Policy, 31(4), 374.

Habib, A. (2008). The role of accruals and cash flows in explaining security returns: Evidence from New Zealand. Journal of International Accounting, Auditing and Taxation, 17(1), 51-66. doi:10.1016/j.intaccaudtax.2008.01.003

Hellström, K. (2007). The Value Relevance of Financial Accounting Information in a Transition Economy: The Case of the Czech Republic. European Accounting Review, 15(3), 37-41. doi:10.1080/09638180600916242

Holthausen, R. W., \& Watts, R. L. (2001). The relevance of the value-relevance literature for financial accounting standard setting. Journal of Accounting and Economics, 31(1-3), 3-75. doi:10.1016/S0165-4101(01)00029-5

Iyoha, F., O., (2012). Compliance with Accounting Standards by Quoted Companies in Nigeria. Nigerian Journal of Education Research $7(2), 25-29$

Isidro, H., \& Grilo, D. (2012). Value-Driving Activities in Euro-Zone Banks. European Accounting Review, 21(2), $297-341$.

Kanagaretnam, K., Mathieu, R., \& Shehata, M. (2009). Usefulness of comprehensive income reporting in Canada. Journal of Accounting and Public Policy, 28(4), 349-365. doi:10.1016/j.jaccpubpol.2009.06.004

Kargin, S. (2013). The Impact of IFRS on the Value Relevance of Accounting Information: Evidence from Turkish Firms. International Journal of Economics and Finance, 5(4), 71-80. doi:10.5539/ijef.v5n4p71

Kasum, A. S. (2007). THE IMPACT OF COMPLIANCE WITH ACCOUNTING STANDARDS ON ASSET AND PROFITABILITY OF NIGERIAN QUOTED. The Journal of Commerce, 3(3), 57-68.

Khurana, I. K., \& Kim, M.-S. (2003). Relative value relevance of historical cost vs. fair value: Evidence from bank holding companies. Journal of Accounting and Public Policy, 22(1), 19-42. doi:10.1016/S0278-4254(02)00084-4

Kim, M., \& Kross, W. (2005). The Ability of Earnings to Predict Future Operating Cash Flows Has Been Increasing-Not Decreasing. Journal of Accounting Research, 43(5), 753-780. doi:10.1111/j.1475-679X.2005.00189.x

Kommunuri, J. (2008). Value Relevance of Accounting Information Subsequent to the Adoption of IFRS in New Zealand, (2005), 20052006.

Kumar, K. R., \& Krishnan, G. V. (2008). The Value-Relevance of Cash Flows and Accruals: The Role of Investment Opportunities. The Accounting Review, 83(4), 997-1040. doi:10.2308/accr.2008.83.4.997

Kwong, L. C. (2010). The Value Relevance of Financial Reporting in Malaysia: Evidence from Three Different Financial Reporting Periods. International Journal of Business and Accountancy, Vol., 1(1), 1-19.

Landsman, W. R. (2007). Is fair value accounting information relevant and reliable ? Evidence from capital market research. Accounting and Business Research Special Issue: International Accounting Policy Forum, 11(24), 19-30.

Lee, C., \& Park, M. S. (2013). Subjectivity in fair-value estimates, audit quality, and informativeness of other comprehensive income. Advances in Accounting, 29(2), 218-231. doi:10.1016/j.adiac.2013.05.003

Li, Z., Shroff, P. K., Venkataraman, R., \& Zhang, I. X. (2011). Causes and consequences of goodwill impairment losses. Review of 
Accounting Studies, 16(4), 745-778. doi:10.1007/s11142-011-9167-2

Liu, C., \& Schaefer, T. F. (1996). Comments Earnings Permanence and the Incremental Information Content of Cash Flows from Operations. Journal of Accounting Research, 34(1), 173-181.

Mechelli, A., \& Cimini, R. (2014). Is Comprehensive Income Value Relevant and Does Location Matter? A European Study. Accounting in Europe, 16(25), 1-35. doi:10.1080/17449480.2014.890777

Mgbame, C. ., \& Ikhatua, O. J. (2013). Accounting Information and Stock Volatility in the Nigerian Capital Market: A Garch Analysis Approach. International Review of Management and Business Research, 2(2), 265-281.

Muthupandian, K. S. (2012). IFRS 7 Financial Instruments: Disclosures - A Closer Look. In The Institute of Cost and Works Accountants of India (pp. 1-9).

Muhammad, Y.A \& Nor, A., L. (2014). Efforts and Challenges in Adopting International Financial Reporting Standards (IFRS) in Nigeria. Journal of Business, Management and Accounting Business Research September, 2014 forth coming

Ohlson, J. A. (2001). Eamings , Book Values, and Dividends in Equity Valuation : An Empirical Perspective *. Contemporary Accounting Research, 18(1), 107-120.

Olatundun, J. A. (2003). Capital Market Efficiency and the Effects of Dividend Announcements on Share Prices in Nigeria. African Development Banks Balckwell Punlishing Ltd, 10(15), 218-237.

Oliveira, L., Rodrigues, L. L., \& Craig, R. (2010). Intangible assets and value relevance: Evidence from the Portuguese stock exchange. The British Accounting Review, 42(4), 241-252. doi:10.1016/j.bar.2010.08.001

Prather-kinsey, J. (2006). Developing countries converging with developed-country accounting standards : Evidence from South Africa and Mexico. The International Journal of Accounting, 41, 141-162. doi:10.1016/j.intacc.2006.04.007

Sanusi, S., L. (2010). 4th Annual Banking and Finance Conference of the Chartered Institute of Bankers of Nigeria (Cibn), Held at the Transcorp, Hiltton, Abuja, Nigeria September. Resaearch Department of the Central Bank of Nigeria (pp. 0-11).

Sanusi, S., L., (2011). Evolving financial landscape - strategies for economic resilience, $4^{\text {th }}$ annual banking and finance conference (September 2011), 1-5.

Tarca, A. (2004). International Convergence of Accounting Practices: Choosing between IAS and US GAAP. Journal of International Financial Management and Accounting, 15(1), 60-91. doi:10.1111/j.1467-646X.2004.00102.x

Tharmila, K., \& Nimalathasan, B. (2013). The value relevance of accounting information and its impact on market vulnerability : a study of listed manufacturing companies in Sri Lanka. Merit Research Journals, 1(2), 30-36.

Umoren, A., O., (2009). Accounting Disclosure and Corporate Attribute, eprints.covenantuniversity.edu.ng accessed May 3, 2013 unpublished $\mathrm{PhD}$ thesis

Wang, L I, Alam, p \& Makar, S. (2005). The Value-Relevance of Derivative Disclosures by Commercial Banks : A Comprehensive Study of Information Content Under SFAS Nos 119 and 133. Review of Quantitative Finance and Accounting, 25(2), 413-427.

World Bank, (2004). Report on the Observance of Standards and Codes (ROSC). http://www.worldbank.org/ifa/rosc_aa.htm/2

World Bank, (2011).Reports on the Observance of Standards and Codes (ROSC).http://www.worldbank.org/ifa/rosc

Yu, S., \& Fung, K. I. T. (2010). Price Divergence from Fundamental Value and the Value Relevance of Accounting Information*. Contemporary Accounting Research, 27(3), 829-854. doi:10.1111/j.1911-3846.2010.01028. 